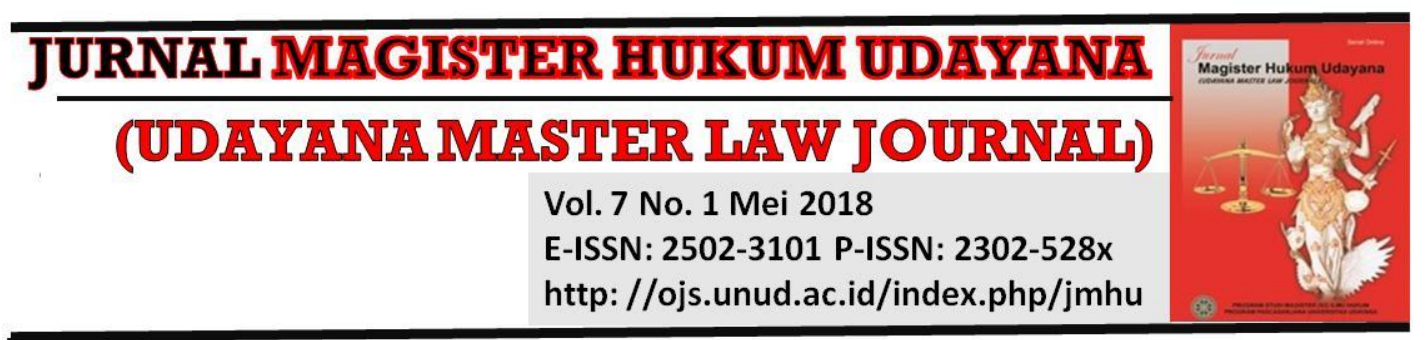

\title{
Hukum Investasi dalam Industrialisasi Kepariwisataan Bali
}

\author{
Putu Tuni Cakabawa Landra ${ }^{1}$
}

1Fakultas Hukum Universitas Udayana, E-mail: putusakabawa@yahoo.com

\begin{tabular}{l}
\hline Info Artikel \\
\hline Masuk : 6 Pebruari 2018 \\
Diterima : 25 Mei 2018 \\
Terbit : 28 Mei 2018 \\
Keywords : \\
Tri Hita Karana, Culture \\
Tourism, Semi- autonomous \\
law \\
\\
\\
\\
Corresponding Author: \\
Putu Tuni Cakabawa \\
putusakabawa@yahoo.com \\
DOI : \\
10.24843/JMHU.2018.v07.i01. \\
p09
\end{tabular}

\begin{abstract}
The threat to agrarian culture values which that why becomes investment object of itself tourism, marked practice of investment of tourism denying cosmology Tri Hita Karana. In other words, implementation of the development of investment of tourism through an institution of investment law in Province of Bali looks on inconsistent applying of law which ended at becoming disappears it itself culture tourism. The investment performance of Tourism in Province of Bali spelled out members hardly phenomenal, followed by the destruction of a norm, structural and source of economics as a result of arranging value liberalistic and individualistic sticking at investment law, with ideology Tri Hita Karana placing forward togetherness principles and balance, runs with the logic is himself. Tourism in Provinsi Bali, which is a manifestation of ideology value totality Tri Hita Karana, where culture is the main specification besides geographical uniqueness and life of its the rituality. Tri Hita Karana becomes a kind of commitment of value about understanding about life, how life must be experienced, and leading base consensus coexists. The arrangement of investment law is not accommodated to this Tri Hita Karana ideology, even in By Law and also development philosophy Province of Bali is affirmed Tri Hita Karana is development manual of Bali in general, and or especially expansion philosophy of cultural tourism. As a result, where ever is happened inconsistency law applying, is beginning from regulation of investment law which just making account of vertical synchronization with higher level regulation or which below his its, and harmonization with regulation on an equal.
\end{abstract}

Abstrak

Objek investasi pariwisata di Bali yang sesungguhnya berakar dari nilai-nilai budaya agraris semakin terancam terlihat dari praktik investasi pariwisata yang semakin inkonsisten dengan fisolofi Tri Hita Karana. Tulisan ini bertujuan untuk mengkaji keberadaan hukum investasi dalam pembangunan investasi pariwisata di Bali dalam kaitannya dengan nilai-nilai dan prinsip Tri Hita Karana. Metode yang dipergunakan adalah metode penelitian hukum doktrinal, dengan pendekatan perundangundangan serta pendekatan konsep, serta dianalisis secara kualitatif. Hasil studi menunjukkan bahwa pembangunan investasi pariwisata di Provinsi Bali inkonsisten dengan nilai filosofi Tri Hita Karana, yang ditandai kian 
menghilangnya pariwisata budaya itu sendiri. Capaian investasi pariwisata di Propinsi Bali yang sangat fenomenal, diikuti oleh keberantakan nilai, norma, struktur dan sumberdaya ekonomi akibat tata nilai liberalistik dan individualistik yang melekat pada hukum investasi. Filosofi Tri Hita Karana mengedepankan prinsip-prinsip kebersamaan dan keseimbangan, sudah seharusnya kepariwisataan di Bali dengan budaya sebagai kekhasan utama, keunikan geografis, dan kehidupan ritualitasnya konsisten dengan Tri Hita Karana. Tri Hita Karana menjadi semacam komitmen nilai tentang pemahaman mengenai hidup, bagaimana hidup harus dijalani, serta konsensus dasar yang menuntun hidup bersama. Pengaturan hukum investasi tidak akomodatif terhadap ideologi Tri Hita Karana., meskipun dalam Peraturan Daerah maupun falsafah pembangunan Provinsi Bali ditegaskan Tri Hita Karana merupakan penuntun pembangunan Bali. Akibatnya, terjadi inkonsistensi penerapan hukum, yang bermula dari regulasi hukum investasi yang hanya sekedar mementingkan sinkronisasi vertikal dengan peraturan yang lebih tinggi atau di bawahnya, dan harmonisasi dengan peraturan perundangan sederajat. Solusinya, penting adanya konstruksi hukum Peraturan Daerah semiotonom

\section{Pendahuluan}

Sejarah mencatat, investasi telah berkembang pesat melalui berbagai pentahapan mulai dari yang terbilang klasik1, yang dikenal dengan sebutan "imperialisme kuno", (abad ke-XVII dan abad ke-XVIII), modern yakni "imperialisme baru", (abad ke-XIX), dan terakhir yang terbilang kontemporer (terjadi sekitar tahun 1960-an), dikala negaranegara berkembang berkenalan dengan investasi sebagai strategi substitusi import.

Gelombang investasi yang disebutkan terakhir ini ditandai oleh terjadinya ledakan investasi dari negara-negara maju ke negara sedang berkembang, dan munculnya liberalisasi investasi sesuai trend perdagangan global yang telah disepakati melalui Agreement on Trade Related Investment Measures (TRIMs) dalam General Agreement on Tariff and Trade (GATT) putaran Uruguay di tahun 1994. Karena, setiap negara penandatanganan TRIMs tidak lagi dibenarkan membuat diskriminasi antara investasi asing dan investasi dalam negeri, inklusif wajib menegasi berbagai halangan rintangan dalam perdagangan (trade barries) ataupun kebijakan pajak yang ketat.

Di Indonesia, investasi mulai berkembang sejak tahun 1960-an 2 dengan diintroduksinya Undang-Undang Nomor 1 Tahun 1967 Tentang Penanaman Modal

${ }^{1}$ Lubis, T. M. \& Buxbaum, R. M. (1986). Peranan Hukum Dalam Perekonomian Di Negara Berkembang. Jakarta. Yayasan Obor Indonesia., h. 49-50

2 Ide dasar untuk mengundang strategi substitusi import (PMA) di Indonesia sebenarnya telah ada sejak tahun 1953 dikala RUU Amidjojo dibawah Kabinet Ali Sastro ke-2 diajukan untuk pertama kalinya ke parlemen. Pengajuan kedua kali atas RUU ini dilakukan pada tahun 1958 dan disetujui menjadi Undang-Undang Nomor 78 Tahun 1958. Pada tahun 1965, dengan 
Asing, dan Undang-Undang Nomor 6 Tahun 1968 Tentang Penanaman Modal Dalam Negeri. Adapun latar permasalahan yang membidani lahirnya kebijakan hukum tersebut, ialah karena di satu pihak keunggulan komparatif yang dimiliki bangsa Indonesia belum dapat dimanfaatkan secara optimal, sementara di pihak lainnya pembangunan ekonomi Indonesia dihadapkan pada kendala ketiadaan dana, dan keahlian yang menyebabkan banyaknya sektor-sektor riil yang tidak/belum dapat diolah dengan kekuatan sendiri.

Setelah lebih kurang 4 (empat) dekade berlaku, Undang-Undang Nomor 1 Tahun 1967 Tentang Penanaman Modal Asing, dan Undang-Undang Nomor 6 Tahun 1968 Tentang Penanaman Modal Dalam Negeri, kemudian diganti, dan di satukan dalam UndangUndang Nomor 25 Tahun 2007 Tentang Penanaman Modal. Tidak ada lagi perbedaan antara modal asing, dan modal dalam Negeri. Semuanya diperlakukan sama dengan menempatkan azas non-diskrimasi dengan tidak memberikan perlakuan khusus atas dasar sumber permodalan.

Dalam amar menimbang dari Undang-undang ini ditegaskan minimal 3 (tiga) hal mendasar. Pertama, bahwa dalam rangka demokrasi ekonomi, kebijakan penanaman modal selayaknya selalu mendasari ekonomi kerakyatan yang melibatkan pengembangan bagi usaha mikro, kecil, menengah dan koperasi. Kedua, bahwa untuk mewujudkan kedaulatan politik dan ekonomi, diperlukan peningkatan penanaman modal untuk mengolah potensi ekonomi menjadi kekuatan ekonomi riil melalui modal yang berasal dari dalam maupun luar negeri. Ketiga, bahwa dalam menghadapi perubahan global, perlu diciptakan iklim penanaman modal yang kondusif, promotif, memberikan kepastian hukum, keadilan, dan efisiensi dengan tetap memperhatikan kepentingan nasional.

Dalam kerangka inilah segala atribusi yang menyertai investasi, seperti: competitive advantage, ownership advantage, dalam bentuk penguasaan terhadap intangable assets, sedemikian rupa seharusnya dimanfaatkan bagi pemberdayaan ekonomi nasional. Hal ini penting karena keunggulan komparatif (comparative advantage) ${ }^{3}$ yang dimiliki bangsa Indonesia belum dapat dimanfaatkan secara optimal, akibat ketiadaan dana dan keahlian, yang berdampak pada banyaknya sektor riil yang belum dapat diolah dengan kekuatan sendiri.

Dengan kata lain, investasi dibutuhkan atas 2 (dua) pertimbangan. Pertama, karena peran sentralnya sebagai salah satu strategi substitusi import ekonomi modern, yang

alasan bahwa PMA di Indonesia dianggap sebagai penghisapan atas rakyat Indonesia serta menghambat revolusi Indonesia, investasi asing nyaris tidak mendapat tempat dalam perekonomian Indonesia. Penolakan akan investasi (asing) tampak jelas dari slogan-slogan seperti : Vivery Very Coloso, go to hell with your aid dan lain sebagainya. Tentang perkembangan investasi di Indonesia secara periodik, lihat Soemantoro. (1986). Hukum Ekonomi. Jakarta. IU PRESS. h. 324-325. Bandingkan pula dengan, Robert Fabrikan, "Sejarah Hukum Perusahaan Negara Indonesia", dalam Lubis, T. M. \& Buxbaum, R. M. Op Cit, h. 215-221.

${ }^{3}$ Keunggulan komparatif (comparative advantage) ialah stabilitas ekonomi dan politik, tenaga kerja murah dan sumber kekayaan alam yang melimpah. Keunggulan komparatif ini harus didukung oleh keunggulan kompetitif (competitive advantage) yang nanya dimiliki investor asing, seperti: penguasaan akses ke pasaran Internasional, distribusi manajemen dan pengalaman usaha. 
diyakini mampu mengantar perekonomian suatu negara ke arah modernitas ataupun industrialitas. Kedua, karena fungsinya yang dapat menggerakkan sektor riil perekonomian negara.

Studi-studi terdahulu membuktikan peran dan fungsi investasi tersebut tidak linier, ada yang menemukan investasi berperan positif dan ada juga menemukan hal sebaliknya. Temuan Frederic C. Deyo di negara-negara sedang berkembang di Asia, mensinyalir bahwa peran investasi selain cukup menonjol juga bervariasi. Deyo menjelaskan, secara umum investasi (asing) di negara-negara industri baru di Asia telah berperan memperlancar dan menyeimbangkan neraca pembayaran, menyediakan teknologi dan tenaga ahli, dan membuka hubungan-hubungan pasar (market channel) yang dibutuhkan dalam rangka pembangunan ekonomi yang berorientasi keluar. ${ }^{4}$

Studi perihal "Hukum Investasi dalam Kerangka Industrialisasi Pariwisata" dengan mengambil setting Provinsi Bali, sebagaimana tema pokok penelitian ini, dilakukan dengan mempertimbangkan 4 (empat) asumsi dasar tersebut di atas. Realitas menunjukkan, dinamika investasi di Provinsi Bali khususnya di bidang pariwisata, terbilang sangat fenomenal. Dalam kurun waktu 1967-2007, investasi di bidang pariwisata dan perdagangan mencapai Rp.13,1 triliun, sedang investasi bidang pertanian dan pengairan hanya Rp. 232,5 miliar. $^{5}$

Bersamaan dengan keberhasilan investasi di sektor pariwisata yang mampu mendongkrak Produk Domestik Regional Bruto (PDRB) Provinsi Bali tersebut, maraknya kegiatan pariwisata turut pula membukukan sejumlah persoalan pelik sebagai eksesnya, yang lebih kurang dapat dipilah 3 (tiga) persoalan mendasar. ${ }^{6}$ Pertama, persoalan kebijakan hukum tingkat regional yang mengatur pariwisata. Secara umum, kebijakan cenderung sektoral, sporadik, dan parsial (tidak koordinatif), tidak ada visi, misi yang sistemik/terintegral, aplikasi kebijakan hukum yang tidak jalan, adanya diskrepansi (kesenjangan) antara kebijakan yang dititik-beratkan pada karakter budaya dengan peraturan perundangan yang mengatur pariwisata sebagai kegiatan bisnis, dan tidak adanya kebijakan yang berfungsi membina komunitas bisnis pariwisata dengan pelestarian lingkungan alam dan budaya Bali.

Kedua, persoalan lingkungan dan sosial-ekonomi. Dari aspek lingkungan pemanfaatan Sumber Daya Alam dan Budaya Bali dalam rangka pariwisata, tergolong sudah

${ }^{4}$ Deyo mencontohkan, dengan modal asing, Hong Kong dan Singapura telah beralih dari negara "gudang" barang menjadi Pusat industri penghasil barang (manufacturing center) yang berorientasi eksport; sedangkan Korea Selatan dan Taiwan, dengan modal asing, telah beralih dari negara pengeksport komoditas primer menjadi negara eksport. Sementara bagi Indonesia dan Malaysia lebih tepat disamakan dengan Korea Selatan dan Taiwan, disamping sebuah kenyataan menunjukkan bahwa, dengan modal asing, kedua negara ini telah dapat mengatasi masalah pengangguran; Lihat, Dayo, F. C. (1987). The Political Economic of The New Assean Industrialism. USA. Cornel University Press. p. 86-87.

${ }^{5}$ Sumber BKPMD Provinsi Bali, 2008.

${ }^{6}$ Penggolongan ini dirangkum dari beberapa sumber terkini, yakni: Suasta, P. (2001). "FIP2B dan Politik Ekonomi Daerah Bali" dalam buku: Menggugat Bali: Potret Perjalanan FIP 2B. Bali. Forum Independen Pemantau Pembangunan Bali.h. 50-63. Putra, I. B. W. (1998). Bali Dalam Perpektif Global. Denpasar. PT. Upada Sastra.; dan Bali Post. (2004). Ajeg Bali: Sebuah Cita-Cita. Denpasar. Bali Post. 
mengancam. Banyak bangunan yang didirikan di Daerah-Daerah yang semestinya dijauhkan dari pembangunan fisik, seperti: di Daerah resapan air, jurang atau Daerah aliran sungai. Dari aspek sosial, pariwisata justru mengkondisikan ketidak-adilan secara sosial. Pariwisata bukan untuk semua, karena hanya lapisan tertentu saja dari masyarakat Bali yang menikmati hasil dari pariwisata. Demikian pula secara ekonomi. Sebagai akibat distribusi pariwisata yang tidak merata, baik antar lapisan masyarakat maupun antar Daerah 7, jurang kaya-miskin dan ketimpangan dalam perolehan Pendapatan Asli Daerah (PAD) antar tiap Kabupaten di Provinsi Bali, tak terhindarkan. Selanjutnya, bila dilihat dari perolehan PAD Kabupaten/ Kota pada tahun yang sama, $75 \%$ dari total PAD, berasal dari Kabupaten Badung dan Kota Denpasar, dan sisanya 25\% merupakan perolehan 7 (tujuh) Kabupaten lainnya.

Ketiga, persoalan budaya dan problematika tanah bagi masyarakat Bali. Kebajikan "Tri Hita Karana" dalam budaya Bali yang telah diadopsi menjadi falsafah pembangunan Provinsi ini, nyata-nyata telah dikorbankan demi pariwisata. Dalam hubungan dengan tanah, Tri Hita Karana mengajarkan antara manusia (masyarakat Bali) dengan lingkungan (tanah) seyogyanya terjadi harmonisasi, dalam arti 'tanah' merupakan bagian yang tak terpisahkan dari masyarakat Bali. Kenyataan menunjukkan, tanah yang diperuntukkan bagi lahan pertanian, pelaba pura yang merupakan kawasan suci, dan atau bibir pantai yang merupakan tempat prosesi keagaamaan sekali pun, semuanya telah dikorbankan demi pariwisata.

Banyak pula yang menganggap aspek keuntungan itu jauh lebih kecil jika dibandingkan dengan resiko yang diterima bagi masa depan Bali dan orang Bali. ${ }^{8}$ Tata Ruang Bali yang berlandasan filosofis Tri Hita Karana kurang diperhatikan, pembangunan fisik dilakukan pada pinggir danau, pinggir sungai, di perbukitan, di jurang, atau tepi pantai. Padahal kawasan-kawasan tersebut, oleh masyarakat Bali dipandang sebagai kawasan suci yang disakralkan. Proses profanisasi terhadap kawasan suci atau tempat-tempat yang disakralkan, jelas merupakan gangguan terhadap keberadaan budaya dan kepercayaan orang Bali.

Resiko lain yang merupakan ancaman bagi Bali dan juga pariwisata Bali adalah merosotnya kelestarian nilai-nilai agama, adat-istiadat, sosial budaya, dan mutu lingkungan hidup masyarakat. ${ }^{9}$ Kawasan penyangga dikembangkan untuk hotel dan usaha pariwisata lainnya. Alih fungsi lahan tidak terkendali. Akibatnya, kondisi alam lingkungan Pulau Bali telah rusak dan tercemar, kerusakan pantai dan hutan bakau terus berlanjut. Sumber daya alam terutama sumber daya air dan tanah semakin menipis, hal ini diakibatkan oleh kegiatan pembangunan di sektor pariwisata, yang sangat rakus, lapar, dan haus akan tanah dan air. Kenyataan tersebut di atas menunjukkan bahwa pariwisata budaya yang dikembangkan oleh pemerintah untuk

\footnotetext{
${ }^{7}$ Daerah terpadat investasi disektor pariwisata adalah Kabupaten Badung dan Kota Denpasar, sedangkan 7 (tujuh) Kabupaten lainnya seperti: Gianyar, Tabanan, Buleleng, Bangli, Karangasem, Klungkung dan Jembrana, tergolong Kabupaten yang minus investasi sektor pariwisata.

8 Triguna,Y. (1997). Mobilitas Kelas, Konflik, dan Penafsiran Kembali Simbolisme Masyarakat Bali, Bandung. Desertasi, Universitas Padjadajaran. h. 14. Lihat pula Krepun, K. (203). Masa Depan Pariwisata Bali. Majalah Sarad. No: 43. Suparta, W. (1999). Bali dan Masa Depan. Denpasar. Penerbit Bali Post. h. 6-11.

9 Pangdjaja. (1991). Bali Apa Kata Mereka. Denpasar. Mabhakti. h. 85.
} 
mempertahankan nilai-nilai, norma-norma agama, adat dan budaya serta kehidupan alam Bali yang berwawasan lingkungan, sangat jauh dari harapan.

Hal menarik dari sejumlah persoalan tersebut adalah bahwa kegiatan investasi di sektor pariwisata di Provinsi Bali tidak mungkin dihentikan hanya karena membawa sejumlah ekses, atau karena keterbatasan lahan yang diperuntukkan bagi kegiatan pariwisata. Investasi sektor pariwisata di Provinsi Bali tetap akan menjadi primadona unggulan, yang untuk itu diperlukan berbagai studi baik dalam rangka memberdayakan investasi di bidang tersebut bagi perekonomian masyarakat Bali, maupun dalam rangka meminimalisasi ekses yang ditimbulkannya.

Pertama, pada era Otonomi Daerah yang disentralisir dewasa ini, cukup banyak penelitian yang mengungkapkan bahwa penerapan Otonomi Daerah sebagaimana dimaksudkan oleh Undang-Undang Republik Indonesia Nomor 22 Tahun 1999, yang telah diperbaharui menjadi Undang-undang Republik Indonesia Nomor 32 Tahun 2004 telah mendatangkan masalah pelik bagi dunia usaha, tak terkecuali kegiatan investasi di Daerah. Kondisi ini menandai policy evaluation, policy approximation dan policy recomendation di bidang hukum investasi (di tingkat nasional maupun regional) menjadi penting untuk dilakukan. ${ }^{10}$

Kedua, bahwa untuk mengadakan pengaturan yang sesuai kebutuhan riil masyarakat di satu Daerah, Undang-Undang Nomor 22 Tahun 1999, yang telah diperbaharui menjadi Undang-undang Nomor 32 Tahun 2004 memberikan kewenangan kepada Daerah Otonom untuk mengatur dan mengurus rumah tangga Daerahnya, dalam 3 (tiga) matra tindakan, yaitu: (1) pembagian kekuasaan untuk mengelola pemerintahan (governmental power sharing) antara Pusat dan Daerah, (2) pembagian keuangan dan personalia negara (financial and manpower sharing), dan (3) pelimpahan kekuasaan politik, adat dan budaya (political and social culture power) kepada Daerah. ${ }^{11} \mathrm{Hal}$ ini berarti pula bahwa, Daerah Otonom diberi kewenangan penuh untuk mengatur (mengadakan regulasi) sesuai kebutuhan dari setting sosial dan budaya di daerahnya masing-masing.

Ketiga, bahwa khusus untuk Provinsi Bali yang padat persoalan investasi (khususnya, kepariwisataan) sebagaimana dipaparkan sebelumnya, dibutuhkan kebijakan hukum yang holistik dan integral sebagai alternatif meminimalisasi ekses yang ditimbulkan

${ }^{10}$ Tim Peneliti FE UI, mengungkapkan Otonomi Daerah menghambat investasi, diindikasikan oleh beberapa hal, yaitu: dualisme aturan perundang-undangan (di satu pihak masih ada UU No. 1 Tahun 1967 j.o UU No. 11 Tahun 1970 Tentang PMA, sementara di pihak lainnya ada UU No. 22/1999 yang sudah direvisi dengan UU No.32/2004 Tentang Pemerintah Daerah) yang juga memberi kewenangan kepada Pemerintah Daerah untuk mengelola investasi. Selain itu Japan External Trade Organization (JETRO), mensinyalir terjadinya capital flight dalam bentuk relokasi di industri ke negara lain dari Indonesia, terbanyak disebabkan oleh local government yang tidak kondusif bagi iklim investasi. Baca, Curdia, V. \& Woodford, M. (2010). Credit Spreads And Monetary Policy. Journal of Money, Credit and Banking. 42(s1), 3-35.

${ }^{11 E s e n s i ~ O t o n o m i ~ D a e r a h ~ t e r s e b u t ~ d i r a n g k u m ~ d a r i ~ b e r b a g a i ~ s u m b e r, ~ a n t a r a ~ l a i n: ~ B r a t a k u s u m a s a, ~}$ Supriady D. \& Solihin, D. (2002). Otononomi Penyelenggaraan Pemerintahan Daerah. Jakarta. PT. Gramedi Pustaka Utama. Rasyid, M. R. (2000). Kebijakan Otonomi Daerah Dan Peran DPRD. dalam "Panduan Parlemen Indonesia". Jakarta. Yayasan API. dan, Lubis, M. S. (2000). Otonomi Daerah, dalam, Nasution, M.A. (2000). Demokratisasi \& Problem Otonomi Daerah. Bandung. CV. Mandar Maju. 
investasi yang umumnya berada di sektor pariwisata, dalam rangka menjaga Ideologi Tri Hita Karana sebagai filosofi pembangunan Provinsi Bali. Idelogi ini sedang giatgiatnya dicanangkan dan diadopsi menjadi falsafah Pembangunan Provinsi Bali, yang lebih populer dikenal dengan konsep Ajeg Bali.12 Konsep ini merupakan pandangan dunia kehidupan masyarakat Hindu Bali tentang bagaimana idealnya pembangunan fisik maupun non fisik dilaksanakan, tak terkecuali di bidang pembangunan investasi kepariwisataan sekali pun.

Berdasarkan latar belakang tersebut maka esensi permasalahan yang dijadikan fokus studi, yaitu bagaimanakah keberlakuan hukum investasi (baik filosofis, sosiologis, maupun yuridis-formal) dalam industrialisasi pariwisata di Provinsi Bali? Serta, bagaimanakah konstruksi hukum investasi kepariwisataan yang ideal bagi Provinsi Bali di era Otonomi Daerah dewasa ini?

Originalitas dari penelitian ini yang merupakan uraian dari penelitian-penelitian terdahulu sebagai berikut, pertama penelitian oleh Dewa Nyoman Gede Suatmaja berjudul Peranan Majelis Desa Pakraman Bali Dalam Pelaksanaan Investasi Kepariwisataan Di Wilayah Desa Pakraman ${ }^{13}$ kedua penelitian oleh I Kadek Yudhi Pramadita berjudul Perjanjian Kerjasama Pengelolaan Pariwisata Tanah Lot Antara Pemerintah Daerah Kabupaten Tabanan Dengan Desa Pakraman Beraban Dalam Perspektif Keadilan Dan Kepastian Hukum ${ }^{14}$, ketiga penelitian oleh Made Suksma Prijandhini Devi Salain berjudul Pengaturan City Hotel Berkarakter Chain Hotel Sebagai Salah Satu Bentuk Usaha Jasa Pariwisata Di Indonesia (Studi Kasus Di Bali) ${ }^{15}$. Ketiga penelitian terdahulu tersebut belum ada yang membahas tentang analisis hukum investasi dalam kerangka industrialisasi pariwisata sehingga penelitian ini merupakan kajian yang mempunyai nilai kontribusi baru dalam ilmu pengetahuan.

Tujuan penelitian ini secara umum adalah mengungkapkan politik hukum di bidang investasi yang tampak mengandung diskrepansi dan problematik, dan sekaligus juga menjelaskan kerangka pikir (yang seharusnya) bagi pembentukan kebijakan hukum investasi pada umumnya, dan atau yang sesuai dengan kebutuhan Provinsi Bali sebagai Daerah tujuan investasi di sektor pariwisata terbesar di Indonesia sedangkan tujuan secara khusus adalah Menjelaskan keberlakuan hukum investasi (baik filosofis, sosiologis, maupun yuridis-formal) dalam kerangka industrialisasi pariwisata di Provinsi Bali dan Merumuskan rancang bangun hukum investasi kepariwisataan yang ideal bagi Provinsi Bali di era Otonomi Daerah dewasa ini.

12Pitana (2008). Bali is Bali Forever : Ajeg dalam Bingkai Tri Hita Karana, Denpasa. Bali Post, h. 3-4.

${ }^{13}$ Gede Suatmaja, D. (2016). Peranan Majelis Desa Pakraman Bali Dalam Pelaksanaan Investasi Kepariwisataan Di Wilayah Desa Pakraman. Jurnal Magister Hukum Udayana (Udayana Master Law Journal). 5(2). 353 - 367. doi:10.24843/JMHU.2016.v05.i02.p10

${ }^{14}$ Pramadita, I. (2017). Perjanjian Kerjasama Pengelolaan Pariwisata Tanah Lot Antara Pemerintah Daerah Kabupaten Tabanan Dengan Desa Pakraman Beraban Dalam Perspektif Keadilan Dan Kepastian Hukum. Jurnal Magister Hukum Udayana (Udayana Master Law Journal). 6(1). 52 - 66. doi:10.24843/JMHU.2017.v06.i01.p05

${ }^{15}$ Prijandhini Devi Salain, M. (2015). Pengaturan City Hotel Berkarakter Chain Hotel Sebagai Salah Satu Bentuk Usaha Jasa Pariwisata Di Indonesia (Studi Kasus Di Bali). Jurnal Magister Hukum Udayana (Udayana Master Law Journal). 4(4). doi:10.24843/JMHU.2015.v04.i04.p17 


\section{Metode Penelitian}

Kerangka kerja dalam penelitian ini dilakukan sesuai metode kajian "penelitian hukum doktrinal", khususnya metode kajian hukum yang mengkonsepkan hukum sebagai perundang-undangan, dan metode kajian hukum yang mengkonsepkan hukum sebagai doktrin atau azas-azas. ${ }^{16}$ Melalui metode kajian hukum positif semua kebijakan hukum investasi (nasional dan regional Provinsi Bali) diinventarisasi, diklasifikasi sesuai perkembangan yang terjadi, lalu dicari premis mayornya pada peraturan yang telah diinventarisasi tadi, untuk selanjutnya dirumuskan silogismesilogisme induksi dan deduksi. Sedangkan melalui kajian hukum yang mengkonsepkan hukum sebagai doktrin, terlebih dahulu dirumuskan silogisme formal (deduksi) dari doktrin/azas hukum yang berlaku universal, kemudian mengkerangkakan pemahaman penafsiran, ${ }^{17}$ baik untuk mengoreksi kebijakan hukum investasi yang berlaku (ius constitutum), maupun untuk proyeksi kebijakan hukum investasi untuk masa yang akan datang (ius constituendum).Pengumpulan data-data kualitatif dilakukan melalui teknik wawancara mendalam (depth intervieuw) kepada para informan yang dipilih secara purposive berdasarkan kompetensi/kewenangan dan atau keterlibatan dalam proses pembuatan, pelaksanaan dan atau menjadi sasaran regulasi kebijakan hukum investasi.

Data yang didapatkan dari penelitian kualitatif adalah data deskriptif yang berwujud rangkaian kata-kata bisa bukan angka-angka, oleh karena itu analisis data dilakukan dengan analisis kualitatif. Dalam analisis kualitatif tidak semata-mata mengungkap suatu gejala saja tetapi memahami gejala itu, tidak saja semata-mata bertujuan mengungkapkan kebenaran saja, tetapi memahami kebenaran itu. ${ }^{18}$ Artinya analisis kualitatif adalah usaha analisis berdasarkan kata-kata yang disusun ke dalam bentuk teks yang diperluas dan disusun secara sistematis.

\section{Hasil Dan Pembahasan}

\subsection{Keberlakuan Hukum Investasi Dalam Kerangka Industrialisasi Pariwisata Di Provinsi Bali}

Keberlakuan hukum secara filosofis ditandai oleh penerimaan seseorang atau kelompok masyarakat terhadap hukum yang sedang berlaku. Penerimaan ini bukan saja karena isi hukum dipandang bernilai atau penting, tapi juga melekatkan

\footnotetext{
16Penelitian Hukum Doktrinal, merupakan upaya inventarisasi hukum positif, penemuan azasazas dan dasar falsafah hukum positif serta upaya menemukan hukum inconcreto. Wignjosoebroto, S. (2002). Hukum, Paradigma, Metode dan Dinamika Masalahnya. Jakarta. Lembaga Studi dan Advokasi Masyarakat (ELSAM). h. 147-156.

${ }^{17}$ Menurut Bloom pemahaman penafsiran merupakan distingsi dari pemahaman terjemahan yang terbatas pada pengubahan simbol hitungan statistik per se, dan pemahaman ekstrapolasi yang menghubungkan antara yang tersurat dan tersirat dengan sesuatu yang ada di luarnya. Dengan distingsi yang demikian, Bloom mengartikan pemahaman penafsiran sebagai upaya menjangkau yang tersirat, bukan hanya yang tersurat, yaitu makna logik atau etiknya, melalui ketajaman berfikir dan juga verstehen untuk menangkap makna universalnya; Endraswati, $\mathrm{H}$., \& Wahyuni, S. (2015). Operationalization of Shariah Marketing Mix in Baitul Maal Wat Tamwil (BMT) at the Province of Banten, Indonesia. Review of Integrative Business and Economics Research. 4(1). 41.

${ }^{18 K r i s t i a n, ~ D ., ~ S u y a t n a, ~ I . ~ N ., ~ \& ~ D a h a n a, ~ C . ~ D . ~(2014) . ~ K e w e n a n g a n ~ P e m e r i n t a h ~ D a e r a h ~ D a l a m ~}$ Pengadaan Tanah Bagi Pelaksanaan Pembangunan Untuk Kepentingan Umum. Kertha Negara, 2(01).
} 
kewajiban untuk patuh dan 'terterima' karena sesuai dengan tata nilai bahkan normanorma yang menjadi standar aturan main dari masyarakat yang bersangkutan.

Dalam konteks keberlakuan hukum investasi dalam kerangka pariwisata di Provinsi Bali, ada paradoks antara tata nilai liberalistik dan individualistik yang melekat pada hukum investasi (baca, Undang-undang Penanaman Modal), dengan ideologi Tri Hita Karana sebagai penuntun segala aspek kehidupan masyarakat Bali. Ideologi Tri Hita Karana ini mengedepankan prinsip-prinsip kebersamaan dan keseimbangan dalam totalitas yang utuh antar subsistem fisik/artefak (lingkungan alam) yang analog dengan gantra pendukung palemahan, subsistem sosial/lingkungan sosial (pawongan), dan subsistem pola pikir/estetika/spiritual (parahyangan).

Persoalan yang muncul kemudian adalah banyak pelaku pariwisata atau pelaku bisnis pariwisata yang tidak memahami apa maksud dari pariwisata budaya tersebut. Pariwisata budaya umumnya hanya dilihat sebagai komoditi bisnis untuk memperoleh keuntungan semata dari bisnis kepariwisataan. Sebagaimana ditulis Sutjipta, kondisi ini ditandai oleh tidak adanya ikatan sistem atau aturan yang berusaha menghubungkan atau membuat mereka peduli dengan sistem sosial dan adat budaya yang ada di Bali. ${ }^{19}$

Konsekuensi logisnya, pemahaman tentang pariwisata budaya, utamanya bagi para pebisnis, hanya terbatas pada hasil karya seni dan perilaku tradisional yang berwujud nyata (kongkrit) dan dapat dilihat dengan mata, misalnya pada lukisan, patung, seni tari, barong, ngaben, pura, persembahyangan (ritual hindu) dan sebagainya. Sedangkan aspek filosofi dibalik budaya yang bersifat abstrak atau tidak dapat dilihat (rohnya budaya Bali) seperti adat istiadat, norma-norma, awig-awig, ajaran agama hindu, filosofi kehidupan Bali yang di dalamnya ada Tri Hita Karana, nyaris tidak banyak dipahami dan tidak terimplementasikan dalam pembangunan pariwisata, bahkan cenderung membawa keberantakan terhadap tata nilai yang diturunkan dari idelogi Tri Hita Karana.

Sesuai ideologi Tri Hita Karana, dunia kehidupan masyarakat Bali terbentuk atas perpaduan yang utuh antara tradisi, agama, kebudayaan dengan nilai-nilai religi, estetika dan solidaritas. Ia menekankan pada suatu keyakinan masyarakat bahwa dalam kehidupan ini harus terjadi harmonisasi antara manusia dengan Tuhan, manusia dengan lingkungan, dan manusia dengan sesamanya. Meminjam Theodore M. Steeman, "Tri Hita Karana" bagi masyarakat Bali adalah komitmen nilai tentang pemahaman mengenai hidup, bagaimana hidup harus dijalani, serta konsensus dasar yang menuntun hidup bersama sebagai bangsa. ${ }^{20}$ Dalam implementasinya, komitmen nilai dipandu oleh nilai dan norma-norma, seperti:

1. "Karma-Phala" suatu standar aturan main agar dalam kehidupan bersama tidak boleh berbuat kejahatan. Norma ini secara sederhana mengajarkan bahwa setiap perbuatan pasti mendatangkan hasil tertentu. Perbuatan baik akan membawa hasil yang baik, sedangkan perbuatan buruk membuahkan hasil yang buruk. Tujuannya,

\footnotetext{
${ }^{19}$ Sutjipta, Pariwisata Revolusi di Pulau Dewata, Universitas Udayana Pers, Denpasar, 2005, hal. 44 ${ }^{20}$ Bandingkan, Theodore M. Steman, "Religious Pluralism and National Integration" (1973), dalam Eka Darmaputera, Op Cit., h. 8
} 
dengan demikian, agar dalam kehidupan keseharian orang takut berbuat jahat, karena khawatir kejahatan itu akan berhadapan dengannya di kemudian hari.

2. "Rwa-Bhineda" suatu tata nilai berupa pengakuan masyarakat Hindu di Bali tentang adanya dua kategorisasi yang secara diametral berbeda dan bersifat abadi selalu mewarnai kehidupan nyata, seperti: baik-buruk, sacral-frofan, hulu-hilir, gununglaut, atas-bawah, laki-perempuan dan sebagainya;

3. "Tat Twam Asi" suatu standar aturan main (norma) dalam kehidupan bersama yang wajib menjunjung kebersamaan dan solidaritas "aku adalah kamu". Kehidupan yang menekankan kebersamaan dan kerjasama antara individu dengan individu, individu dengan kelompok dan antara kelompok dengan kelompok;

Nilai dan norma-norma tersebut kemudian lebih mengkristal lagi menjadi stándar perilaku keseharian bagi masyarakat Bali. Norma-norma ini berlaku secara imperatif, tak terkecuali dalam pengelolaan pariwisata. Dalam logika norma keseimbangan, pelaku pariwisata dan komunitasnya adalah unsur pawongan (lingkungan sosial), kawasan wisata beserta infrastrukturnya sebagai unsur palemahan (lingkungan alamiah) dan pemujaan pelinggih Dewi Laksmi yang ada di setiap kawasan wisata (hotel, restauran, lapangan golf, villa, dan lainnya) sebagai unsur parahyangan (lingkungan spiritual).

Dengan kata lain, idealnya pengelolaan kepariwisataan tidak terpilah tetapi merupakan satu kesatuan yang holistik dan terintegrasi. Fakta menunjukkan pengelolaan pariwisata melalui hukum investasi sebagai instrumennya, menafikan nilai keseimbangan tersebut.

Industrialisasi pariwisata di Provinsi Bali membawa keberantakan nilai dan normanorma yang ditandai oleh proses profanisasi tempat-tempat suci bagi kepentingan pariwisata. Besarnya investasi pariwisata ke Pulau Bali berdampak buruk pada tata lingkungan dan kehidupan masyarakat Bali. Tata Ruang Bali yang berlandasan filosofis Tri Hita Karana kurang diperhatikan, pembangunan fisik dilakukan pada pinggir danau, pinggir sungai, di perbukitan, di jurang, atau tepi pantai membahayakan kelestarian lingkungan alam. Padahal kawasan-kawasan tersebut, oleh masyarakat Bali dipandang sebagai kawasan suci yang disakralkan.

Nilai dan norma keseimbangan dari idelogi Tri Hita Karana ditegakkan oleh struktur (baca, kelembagaan informal) seperti: Banjar, Desa Adat atau lebih populer disebut desa pakraman, Subak, dan lain-lain.

Sesuai idelogi Tri Hita Karana, Desa Adat dan Subak menegakkan norma-norma Desa Kala Patra, Tri Mandala, Yadnya, Karma Phala di aktualisasikan dalam berbentuk: Awigawig, Perarem dan Paswara yang memuat berbagai macam regulasi sosial tentang Sukerta Tata Parhyangan yaitu aturan-aturan mengenai hubungan manusia dengan Tuhan Yang Maha Esa, Sukerta Tata Pawongan/Pakraman, yaitu aturan-aturan mengenai hubungan manusia dengan manusia/lingkungan sosial masyarakatnya, dan Sukertha tata Palemahan yaitu aturan-aturan mengenai hubungan manusia dengan alam lingkungannya. 
Peranan Desa Adat dan Subak dalam mengatur segi kehidupan masyarakat Bali, faktual jauh melebihi peran institusi formal/pemerintah. ${ }^{21}$ Desa Adat dan Subak dengan berbagai perangkatnya seperti Prajuru Adat, Pecalang, Sabha Desa dan Sabha Kertha adalah merupakan lembaga tradisional yang memiliki peranan yang sangat penting dalam menjaga kelestarian alam, budaya bahkan kehidupan religiustitas masyarakat Bali.

Hakikat keberadaan lembaga-lembaga ini adalah menjaga keharmonisan hubungan antara manusia dengan manusia, manusia dengan Tuhan (lingkungan spiritual), lingkungan sosial dan lingkungan alamiah dalam rangka mencapai kesejahteraan hidup lahir dan batin. Tujuannya adalah agar aktivitas keseharian masyarakat Hindu Bali tertata sesuai falsafah hidup berdasarkan Tri Hita Karana yang sudah diyakini dan dipercaya serta dipraktekkan dalam kehidupan sosial yang sudah berlangsung selama berabad-abad

Peran kelembagaan social yang ada untuk beberapa tempat masih cukup memadai dalam melestarikan dan atau menegakkan nilai/norma Tri Hita Karana. Untuk menyebut beberapa diantaranya keberhasilan yang ditunjukan oleh Desa Adat dalam pengelolaan dan pelestarian obyek wisata di beberapa tempat seperti: Obyek wisata Desa Tenganan Pegringsingan di Kabupaten Karangasem, Obyek Wisata Desa Pengelipuran di Kabupaten Bangli, Obyek Wisata Goa Lawa di Desa Pesinggahan, Kabupaten Klungkung, Obyek Wisata Burung Bangau Putih di Desa Petulu Kabupaten Gianyar, Obyek Wisata flora dan fauna di Desa Sangeh, Kabupaten Badung dan Desa Kukuh, Kabupaten Tabanan, dan Obyek Wisata lainnya, ditemukan berbagai bentuk kearifan lokal masyarakat baik dalam bentuk nilai/konsep, upacara/ritual, mitos, awig-awig maupun dalam bentuk organisasi/lembaga sosial tradisional. ${ }^{22}$ Namun demikian, berbarengan dengan keberhasilan tersebut, kelembagaan sosial yang ada (misalnya, Subak), juga membukukan kemunduran peran kalau tidak hendak dikatakan kehilangan fungsi utamanya sebagai pengelola lahan pertanian. Sebagai akibat ekploitasi terhadap lahan pertanian mengakibatkan terjadinya proses marginalisasi terhadap petani dan penduduk lokal (petani Bali), terutama di Kota Denpasar, kelembagaan subak menjadi tidak eksis lagi. Konsekuensi logisnya nilai-nilai budaya yang ada pada subakpun ikut terdegradasi, di samping lahan pertanian pun beralih fungsi dan makin tidak terkendali.

Bali sebagai pusat pariwisata Indonesia bagian tengah dan pintu terdepan pariwisata Indonesia sudah mengalami degradasi pada kualitas alamnya. Pertanian sebagai salah satu sektor andalan kurang diperhatikan, bahkan cenderung dikorbankan demi pariwisata. Akibat pengembangan pariwisata yang tidak tertata dengan baik, membawa dampak negatif terhadap alam lingkungan dan budaya Bali yang seharusnya dipelihara dan dilestarikan dalam posisinya sebagai komoditas pariwisata Bali. Ruang publik seperti taman, alun-alun, hutan, tebing bahkan kawasan tempat suci (Pura) pun sudah berubah dan dirambah menjadi, Hotel, Restoran, Bank, Swalayan, Ruko, Lapangan Golf, dan obyek wisata lainnya. Bali sekarang dijuluki pulau seribu Hotel dan Ruko, bukan lagi sebagai pulau seribu Pura.

\footnotetext{
${ }^{21}$ Hasil Penelitian Desertasi, Putu Gelgel. ( ). Kearifan Lokal Dalam Pembangunan Hukum Pariwisata di tengah Arus Globalisasi Perdagangan Jasa. Semarang. Program Doktor Ilmu Hukum UNDIP.

${ }^{22}$ Ibid.
} 
Fenomena memprihatinkan ini membawa 2 (dua) implikasi sekaligus, yakni hilangnya ekonomi subsisten agraris, di samping budaya agraris itu sendiri yang justeru menjadi daya tarik utama bagi para pelancong untuk berkunjung ke Pulau Bali. Budaya agraris yang terpinggirkan akibat alih fungsi lahan pertanian antara lain, hilangnya upacara keagamaan yang dilakukan baik secara individual maupun berkelompok oleh para petani sebagai ekspresi atau pemujaan petani dengan Tuhan, dan pengakuan petani bahwa tanaman merupakan karunia Tuhan sehingga tanaman harus dipelihara dengan baik. Pembangunan pariwisata di samping mengambil tanah pertanian dengan segala konsekuensi pada upacara keagamaan yang menyertainya, juga pengambilalihan pemanfaatan air yang seharusnya untuk kepentingan pertanian bagi kepentingan pembangunan pariwisata. Akibatnya, muncul kecenderungan krisis air bersih. Hal ini sebagaimana terungkap dalam loka karya yang digelar Japan International Cooperation Agency terungkap bahwa paling tidak dalam waktu 20 tahun mendatang Bali akan mengalami krisis air bersih. Resiko lain yang merupakan ancaman bagi Bali dan juga pariwisata Bali adalah merosotnya kelestarian nilai-nilai agama, adat-istiadat, sosial budaya dan mutu lingkungan hidup masyarakat. ${ }^{23}$ Kawasan penyangga dikembangkan untuk hotel dan usaha pariwisata lainnya. Alih fungsi lahan tidak terkendali. Kondisi alam lingkungan Pulau Bali telah rusak dan tercemar, kerusakan pantai dan hutan bakau terus berlanjut.

Sumber daya alam terutama sumber daya air dan tanah semakin menipis, hal ini diakibatkan oleh kegiatan pembangunan di sektor pariwisata, yang sangat rakus, lapar, dan haus akan tanah dan air. Kenyataan tersebut di atas menunjukkan bahwa, pariwisata budaya yang dikembangkan oleh pemerintah untuk mempertahankan nilai-nilai, norma-norma agama, adat dan budaya serta kehidupan alam Bali yang berwawasan lingkungan, sangat jauh dari harapan. Industrialisasi pariwisata di Propinsi Bali telah dapat membawa dampak positif dalam meningkatkan perekonomian masyarakat dan negara, seperti; meningkatkan perekonomian rakyat, meningkatkan pendapatan daerah, menambah devisa negara, meningkatkan peluang kerja, berkembangnya industri kerajinan masyarakat, serta menarik para investor guna menanamkan modalnya di bidang usaha pariwisata. Namun disisi yang lain, dibalik keberhasilan tersebut banyak pula yang menganggap aspek keuntungan itu jauh lebih kecil jika dibandingkan dengan resiko yang diterima bagi masa depan Bali dan orang Bali. $^{24}$

Dalam rangka industri kepariwisataan, sikap-tindak yang tidak bersesuaian dengan hukum, juga tak pelak terjadi demi dan untuk kepentingan pariwisata seperti pembangunan Villa tanpa izin untuk mendukung pariwisata, dan atau adanya izan lokasi wisata yang menyalahi tata ruang. Studi ini menunjukkan bahwa peraturan yang ada masih bercorak sektoral, belum memperhatikan kelestarian alam dan budaya Bali sebagai satu kesatuan geografis yang holistik integral. Alam dan budaya Bali hanya dipandang sebagai komoditas bisnis semata, tanpa ada political-will yang kuat dari pemerintah untuk memproteksinya melalui peraturan hukum. Peraturan hukum yang ada belum mampu mengendalikan perilaku positif para pengusaha pariwisata dalam membangun tradisi bisnis yang sehat dan bertanggung jawab terhadap kelestarian alam dan budaya Bali yang sesungguhnya adalah asset dalam kegiatan bisnisnya. Kenyataan ini diperparah lagi dengan lemahnya semangat

23Pangdjaja, Op.cit, h.. 125.

${ }^{24}$ Yudha Triguna, Op Cit., h. 14. 
penegakan hukum (law enforcement) dalam memelihara kualitas, keamanan dan pelestarian alam dan budaya Bali. Namun demikian, ditengah inkonsitensi penerapan hukum dalam kerangka industrialisasi pariwisata, terdapat regulasi sosial yang terbilang kondusif menjaga tata nilai Tri Hita Karana. Hasil penelitian menunjukkan bahwa para penegak norma-norma social dalam organisasi tradisional baik dalam Desa Adat maupun Subak seperti: Prajuru Adat/Subak, Sabha Desa, Sabha Kertha dan Pecalang, memiliki kemampuan yang sangat andal dalam menegakkan aturan-aturan (Awig-awig) yang berlaku di wilayahnya masing-masing secara bijaksana dan adil. ${ }^{25}$

Dari aspek obyek, hukum investasi memiliki cakupan yang sangat luas dan terbuka. Dikatakan sangat luas karena dapat meliputi setiap tindakan dan hubungan hukum yang bertujuan membelanjakan modal dalam rangka memperoleh pendapatan. Disebutkan bersifat terbuka mengingat bidang-bidang yang merupakan obyek hukum investasi tidaklah permanen, melainkan tunduk kepada hukum yang mengaturnya. Dengan demikian dapat dikemukakan, obyek-obyek tersebut tidaklah statis tetapi akan mengalami dinamika perkembangan secara berkesinambungan. Hukum Investasi tidak semata-mata mengatur hubungan hukum keperdataan yang terjadi di antara para investor, tetapi juga mengatur dan menentukan mengenai berbagai tindakan pemerintah berkenaan dengan kegiatan investasi yang pada dasarnya merupakan aktivitas keperdataan tersebut. Dalam perspektif ini terkandung pengertian bahwa hukum investasi pada satu sisi memiliki dimensi hukum privat dan pada sisi lain membutuhkan partisipasi dari dimensi hukum publik.

Pengaturan hukum yang terkait dengan kegiatan investasi dalam kerangka industrialisasi pariwisata secara yuridis diatur dalam beberapa produk hukum antara lain adalah: Undang-Undang Republik Indonesia Nomor 10 Tahun 2009 Tentang Kepariwisataan, Undang-undang Republik Indonesia No. 25 Tahun 2007 Tentang Penanaman Modal, Undang-undang Republik Indonesia No. 26 Tahun 2007 Tentang Penataan Ruang dan Undang-undang Republik Indonesia No. 32 Tahun 2004 Tentang Pemerintah Daerah Secara normatif proses sinkronisasi Perundang-undangan diatas yang terkait dengan kegiatan investasi baik horizontal maupun vertikal dapat dilihat dari uraian berikut.

Undang-Undang Penanaman Modal mengatur tentang Bidang-Bidang Usaha yang terbuka dan tertutup bagi kegiatan penanaman modal. Pemerintah wajib menetapkan bidang usaha yang dicadangkan untuk usaha mikro, kecil, menengah dan koperasi serta bida usaha yang terbuka untuk usaha besar dengan syarat harus bekerjasama dengan usaha mikro, kecil, menengah dan koperasi. ${ }^{26}$ Ketentuan ini secara horizontal selaras dengan ketentuan yang diatur dalam Undang-Undang Kepariwisataan bahwa Bidang-bidang yang menjadi ruang lingkup atau obyek investasi kepariwisataan diatur dalam Undang-Undang Republik Indonesia No. 10 Tahun 2009 Tentang Kepariwisataan adalah usaha-usaha yang meliputi ${ }^{27}$ a) daya tarik wisata, b) kawasan pariwisata, c)jasa transportasi wisata, d) jasa perjalanan wisata, e) jasa makanan dan minuman, f) penyediaan akomodasi, g) penyelenggaraan kegiatan hiburan dan rekreasi, h) penyelenggaraan pertemuan, perjalanan insentif, konferensi, dan pameran i) jasa informasi pariwisata, j) jasa konsultan pariwisata, k) jasa pramuwisata, l) wisata

\footnotetext{
${ }^{25}$ Gelgel, Loc Cit., h. 115.

26Pasal 12, 13 (1) Undang-Undang Nomor 25 Tahun 2007 Tentang Penanaman Modal

27Pasal 14 Undang-Undang No. 10 Tahun 2009 Tentang Kepariwistaan
} 
tirta; dan m) spa. Pada bidang-bidang inilah investasi kepariwisataan dapat ditanamkan.

Kepariwisataan mempunyai peranan penting untuk memperluas dan memeratakan kesempatan berusaha dan lapangan kerja, mendorong pembangunan daerah, memperbesar pendapatan nasional dalam rangka meningkatkan kesejahteraan dan kemakmuran rakyat. ${ }^{28}$ Penyelenggaraan kepariwisataan dilakukan dalam rangka memperluas dan memeratakan kesempatan berusaha dan meningkatkan kesejahteraan dan kemakmuran rakyat.

Sinkronisasi antara Undang-Undang Nomor 25 Tahun 2007 Tentang Penanaman Modal terhadap Undang-Undang Nomor 32 Tahun 2004 Tentang Pemerintahan Daerah yang terkait dengan kewenangan urusan penanaman modal dapat diuraikan sebagai berikut.

Berdasarkan perumusan normatif tentang kewenangan pengaturan investasi yang terkait dengan jaminan dan kepastian berinvestasi, kewenangan pemerintah baik dipusat, provinsi maupun Kabupaten/kota terkait penyelenggaraan investasi, dan penyelenggaraan penataan ruang yang terkait kegiatan investasi, perundangundangan tentang penanaman modal, penataan ruang dan pemerintah daerah secara normatif telah memenuhi prinsip sinkronisasi secara horisontal.

Secara vertikal pengaruh sinkronisasi pengaturan hukum investasi nasional terhadap pengaturan tingkat regional propinsi Bali dapat dilihat dari pengaturan tata ruang daerah Bali yang terkait dengan kegiatan investasi pariwisata dalam kerangka menyelamatkan alam dan budaya Bali. Politik hukum penataan ruang adalah agar terwujudnya keharmonisan antara lingkungan alam dan lingkungan buatan manusia, adanya keterpaduan dalam penggunaan sumber daya alam dan sumber daya buatan dengan tetap mengindahkan dan memperhatikan sumber daya manusia dan tetap terjaganya perlindungan fungsi ruang serta pencegahan dampak negatif terhadap lingkungan akibat pemanfaatan ruang.

\subsection{Konstruksi Hukum Investasi ‘Semi-Otonom’ Dalam Industrialisasi Pariwisata Di Provinsi Bali : Sebuah Usulan}

Hukum investasi yang didatangkan dalam pengelolaan investasi di Provinsi Bali, sesuai temuan studi ini, hingga taraf tertentu adalah sebuah bencana ketimbang berkah. Faktual, kehadiran hukum investasi dalam dunia kehidupan masyarakat Bali, membawa keberantakan nilai, norma, sumberdaya ekonomi subsisten, bahkan objek pariwisata budaya itu sendiri. Di satu sisi, tertib sosial masyarakat Hindu Bali cenderung bertumbuh sekedar untuk mempertahankan tertib sosial sesuai dengan falsafat Tri Hita Karana, sementara di sisi lainnya cenderung mengingkari keteraturan yang ditawarkan hukum investasi.

Studi yang dilakukan I Putu Gelgel tentang kearifan lokal di Provinsi Bali, hingga taraf tertentu analog dengan apa yang dikemukakan Galanter tersebut. Beberapa instrumen penataan sosial seperti: Tri Hita Karana, Hukum Karmapala, Desa Kalapatra, Tat Twan Asi, Rwa Bhineda, merupakan sejumlah budaya hukum yang tidak anti terhadap pranata hukum di luarnya, tapi juga serta merta mengadopsi sesuatu yang datang luar. Semua akan disaring sesuai ajaran mendasar dari budaya hukum tersebut, dan tentunya yang sesuai/padan dengan kearifan yang diajarkan budaya hukum tersebut

${ }^{28} \mathrm{Ibid}$, Pasal 4 
akan digunakan, sementara yang tidak sesuai dengan sendirinya tidak mendapat tempat. Singkat kata, ketika sesuatu yang datang dari luar tatanan dunia kehidupan, persoalannya kembali pada pilihan 'use', atau 'not use' berdasarkan ukuran tata nilai pandangan dunia kehidupan.

Tatanan hukum positif, tidak mempunyai monopoli jenis apapun terhadap aneka bentuk kepatuhan dan ketaatan sosial di masyarakat. ${ }^{29}$ Meski hukum positif terbilang istimewa, seperti kata Hoebel, karena ada kewenangan paksaan secara sah, tidak begitu berarti pada masyarakat yang lengkap dengan kebajikan sosial di bidang hukum. Malah, seperti dikatakan Moore, penekanan terhadap kemampuan negara untuk menggunakan paksaan yang dilegalkan, tidak menghapus adanya saranasarana dan cara-cara lain untuk mendorong ketaatan pada peraturan. ${ }^{30}$ Umumnya sudah diakui, demikian Falk Moore, bahwa antara negara dan individu terdapat aneka bidang sosial kecil yang terorganisasi di mana individu berpartisipasi. Bidang-bidang sosial ini mempunyai adat kebiasaan, aturan-aturan, dan cara masing-masing dalam memaksa atau mendorong ketaatan.

Faktor budaya hukum, jelas berperan juga di sini. Pandangan-pandangan dan nilainilai yang anut oleh suatu masyarakat Hindu Bali merupakan kekuatan sosial (social force) yang secara langsung atau tidak, mempengaruhi mekanisme bekerjanya hukum secara keseluruhan. Fenomena ini mirip dengan konsepsi teori ini dikemukakan oleh Lawrence Friedman. Menurut Friedman, komponen budaya hukum adalah ide-ide, sikap-sikap nilai-nilai, kepercayaan yang berkaitan dengan hukum ${ }^{31}$. Kultur hukum, demikian Friedman, menjadi motor penggerak bekerjanya hukum (pengadilan) dalam masyarakat. Dipakai tidaknya pengadilan, sangat tergantung pada budaya/kultur hukum dari warga masyarakat yang bersangkutan.

Rancang-bangun hukum nasional yang berporos pada politik kodifikasi dan unifikasi, telah "berhasil" menciptakan bangunan hukum berciri modern ${ }^{32}$. Tapi tentulah kemodernan sistem hukum itu, bukan tanpa masalah. Sebaliknya, bangunan hukum yang bertopang pada politik kodifikasi dan unifikasi itu, membungkus persoalan

\footnotetext{
${ }^{29}$ Sally Falk-Moore, "Hukum dan Perubahan Sosial : Bidang Sosial Semi Otonom Sebagai Suatu Topi Studi yang tepat", dalam Ihromi, T. O. (1993). Antropologi Hukum Sebuah Bunga Rampai. Jakarta. Yayasan Obor Indonesia. h. 148-149.

${ }^{30}$ Choudhury, N. (2017). Revisiting Critical Legal Pluralism: Normative Contestations in the Afghan Courtroom. Asian Journal of Law and Society. 4(1). 229-255..

${ }^{31}$ Friedman, L. M. (1977).The Legal System : A Social Sciente Perspective, New York : Russel Sage Foundation. lihat dalam Edelman, L. B., Krieger, L. H., Eliason, S. R., Albiston, C. R., \& Mellema, V. (2011). When organizations rule: Judicial deference to institutionalized employment structures. American Journal of Sociology, 117(3), 888-954.

${ }^{32}$ Bila diringkas, baik Max Weber, Marc Galanter, maupun R. Unger memberi ciri pada hukum modern sebagai hukum yang bersifat: uniform, otonom, nonpersonal dan teritorial, normatif, positif, sekuler lihat dalam Trubek, D. M. (1991). Max Weber on Law and the Rise of Capitalism. London. Routledge.
} 
tersendiri pada aras praksis ${ }^{33}$, khususnya dalam konteks komunitas lokal dengan keunikan $^{34}$ dan pluralitasnya seperti masyarakat Bali.

Pandangan hidup manusia dan masyarakat Bali didasarkan pada "Tri Hita Karana" yakni "Tri" adalah tiga, "Hita" adalah kesejahteraan dan "Karana" adalah sumber penyebab. Secara harafiah "Tri Hita Karana" artinya adalah : tiga sumber penyebab kesejahteraan yakni hidup dengan mengembangkan keselarasan dengan Tuhan Yang Maha Pencipta, Masyarakat dan Lingkungan Alam Semesta. Tri Hita Karana adalah wujud kearifan lingkungan yang hidup asli berakar dalam hati sanubari masyarakat Bali. Pandangan budaya masyarakat Bali yang tertuang dalam Tri Hita Karana adalah ideologi yang hakiki dalam mewujudkan prinsip-prinsip pembangunan yang berkelanjutan (sustainable development).

Sebagai destinasi pariwisata yang dikunjungi jutaan wisatawan dari berbagai belahan dunia, masyarakat Bali tidak mungkin menutup diri dari pergaulan masyarakat internasional (internasional community relationship). Konsekwensi logis sebuah pergaulan adalah munculnya pengaruh timbal balik antar elemen budaya baik pada level lokal, regional, nasional dan internasional. Bila elemen budayanya kuat maka masyarakatnya tetap eksis, bahkan dengan kekuatan budayanya akan mampu mempengaruhi budaya luar yang kemudian berasimilasi ke dalam budaya lokal. Sebaliknya masyarakat yang memiliki elemen budaya lemah dan pragmatis akan terbawa arus perubahan dan budaya masyarakatnya punah karena menjadi korban keganasan budaya asing.

Format pembangunan pariwisata Bali harus dalam pendekatan satu kesatuan holistik integral Bali. Pengaturan tata ruang Bali tidak boleh dilakukan dengan cara pandang melihat ruang Bali secara terfragmentasi ke dalam delapan kabupaten dan satu kota. Penataan ruang wilayah pada tingkat Kabupaten/Kota haruslah sinkron dengan rencana tata ruang wilayah Provinsi dan penataan ruang Provinsi harus terpadu dengan rencana penataan ruang secara nasional. Atau dengan kalimat yang lain harus ada hierarki Perundang-undangan dari tingkat nasional sampai ke tingkat Kabupaten/Kota yang harus dipatuhi sebagai instrumen hukum yang mengatur rencana tata ruang dan kaidah-kaidah hukumnya harus dapat di diimplementasikan secara konsisten dan berkesinambungan. Sesuai dengan hasil penelitian ditemukan bahwa apabila filosofi "Tri Hita Karana" hendak dijadikan "roh" pembangunan pariwisata Bali, maka secara ideologis falsafahnya harus tampak dalam perencanaan rancang bangun tata ruang Bali, tampak dalam norma dan kelembagaan yang mengatur pola-pola relasi antara kekuasaan negara (pemerintahan daerah) dan otoritas

${ }^{33}$ Dalam catatannya mengenai ide politik kodifikasi yang diberlakukan di Hindia Belanda, Wignjosoebroto mengkonstatasi bahwa politik kodifikasi dan unifikasi hukum merupakan hal yang tetap bertentangan dengan realitas sosial sepanjang abad (Wignjosoebroto, S. (1994). Dari Hukum Kolonial ke Hukum Nasional: Dinamika Sosial Politik Dalam Perkembangan Hukum di Indonesia. Jakarta. Raja Grafindo Persada. h. 37-60.)

34Soal "kesatuan" dan "kebhinekaan", merupakan persoalan permanen untuk Indonesia, yang tentu berimplikasi pada semua kebijakan yang diambil, termasuk dalam pembinaan hukum. Baik "kesatuan" mau pun "kebhinekaan"-nya mempunyai sistem dan dinamikanya sendirisendiri. Hanya menekankan kepelbagaian dan kemajemukan, maka kita akan terperangkap pada situasi keterceberaian. Demikian pula, hanya mempedulikan kesatuannya, kita akan terjebak pada situasi unifikasi primitif yang niscaya totaliter (bandingkan dengan deskripsi akar budaya Bhineka Tunggal Ika dari Darmaputera, E. (1987). Pancasila: Identitas dan Modernitas, Tinjauan Etis dan Budaya. Cetakan 1. Jakarta. Gunung Mulia. h. 13-65. 
agama dan yang terpenting tampak dalam norma dan kelembagaan bagaimana investasi pariwisata dibangun dalam tata ruang Bali tersebut 35

Falsafah ini juga harus tampak dalam norma dan kelembagaan yang mengatur polapola relasi antara kekuasaan negara (pemerintahan daerah) dan kekuasaan adat (banjar, Desa Pakraman, subak). tampak dalam kebijakan dan program-program kesejahteraan sosial Pemerintah Daerah yang dapat dilihat sebagai yang ditarik dari pusat otoritas (Provinsi) hingga tingkat pelaksana lapangan (steet-level bureaucrats). tampak dalam kultur pelayanan umum (public service) dan harus tampak pula dalam mekanisme evaluasi yang memungkinkan rakyat jelata sekalipun dengan mudah memberikan penilaiannya terhadap keberhasilan atau kegagalan pemimpinnya. Dalam penataan ruang Bali yang melihat Bali sebagai satu kesatuan ruang yang holistik integral seharusnya tegas digariskan bagian-bagian mana dari ruang Bali itu yang berkedudukan sebagai kepala, badan dan kakinya (Ulu, madya, dan teben), ${ }^{36}$ dengan pembanding paralelnya adalah konsepsi tri mandala : utama mandala, madya nandala, dan kanista mandala.

Pendekatan penataan ruang Bali yang diuraikan di atas adalah pendekatan dari perspektif yang vertikal-fungsional-kosmologis, sesuai dengan alam pikir masyarakat Bali. Pendekatan demikian harus dipadukan dengan pendekatan dari perspektif horisontal-fungsional-ekonomis. Karena pariwisata sebagai ujung tombak (leading sector) perekonomian Bali maka penataan ruang Bali secara horisontal dapat dibagibagi ke dalam ruang-ruang dengan macam-macam fungsi yang diarahkan untuk menunjang pembangunan pariwisata Bali sebagai leading sector itu. ${ }^{37}$

Otonomi penuh dan luas pada pemerintah Kabupaten/Kota diarahkan untuk menggali seoptimal mungkin sumber pendapatan daerah untuk meningkatkan PAD (Pendapatan Asli Daerah) tanpa mempertimbangkan dampak buruk akibat kebijakan yang diputuskannya. ${ }^{38}$ Dalam format pembangunan pariwisata Bali yang memandang Bali sebagai satu-kesatuan yang utuh holistik-integral maka kebijakan hukum parsial yang dilakukan pemerintah Kabupaten/Kota tersebut berimplikasi negatif terhadap kondisi tata ruang Bali yang berlandaskan pada nilai-nilai agama Hindu dan falsafah Tri Hita Karana. Karenanya format pembangunan pariwisata Bali berdasarkan ideologi Tri Hita Karana harus dalam pendekatan holistik integral yakni Bali sebagai satukesatuan yang utuh pulau Bali.

Tidak bisa dipungkiri bahwa pariwisata sebagai motor perekonomian Bali memberikan sumbangan besar bagi kesejahteraan masyarakat. Namun disisi lain, industrialisasi pariwisata ternyata juga berdampak negatif terhadap pelestarian alam dan budaya Bali yang jiwanya adalah agama Hindu. Pantai yang dahulu digunakan tempat prosesi upacara agama Hindu, kini dibatasi dengan tembok tinggi. Pelaba Pura yang merupakan kawasan suci dikuasai investor. Ringkasnya semua direlakan demi

\footnotetext{
35Palguna, D. G. (2008). Saya Mencemaskan Bali. Jakarta. Mahkamah Konstitusi. h. 25, lihat juga Nyoman Sucipta, Pariwisata Revolusi di Pulau dewata, dan Pitana dalam Daya Dukung Bali terhadap kepariwisataan, menyatakan Tri Hita Karana sebagai "roh" yang menjiwai pariwisata budaya Bali dilestarikan dalam norma-norma rancang bangun pariwisata Bali.

${ }^{36}$ Palguna, D. G. (2008). Implementasi THK dalam Aspek Hukum : Realitas, Harapan, dan Rekomendasi, dalam : Bali is Bali Forever. Denpasar. Bali Travel News. h. 188-200.

37 Ibid.

38 Ibid.
} 
pariwisata. Tata ruang Bali rusak karena proses pembangunan yang tidak terencana, khususnya perencanaan pembangunan pariwisata.

Desa Pakraman sebagai kesatuan masyarakat hukum adat yang dijiwai oleh ajaran agama Hindu sangat besar peranannya dalam bidang agama dan sosial budaya Bali sehingga perlu di revitalisasi eksistensinya, dilestarikan dan diperdayakan untuk mendukung keberlanjutan pembangunan di Provinsi Bali. Sebagai suatu kesatuan masyarakat hukum adat, Desa Pakraman memiliki tradisi yang dilandasi agama Hindu secara turun temurun dalam satu ikatan yang disebut Kahyangan Tiga. Sistem pemerintahan Desa Pakraman sangat demokratis. Pemimpin Desa Pakraman yang disebut prajuru dipilih langsung oleh masyarakatnya. ${ }^{39}$ Namun demikian dari hasil penelitian yang dilakukan ternyata keberpihakan aturan-aturan hukum kepada kepentingan masyarakat itu tidak dapat direalisasikan. Ketidak berdayaan penegakan Perda tersebut mengakibatkan berbagai kepentingan masyarakat tidak dapat terakomodasi dan dikorbankan demi kepentingan pariwisata.

Terkait dengan kewenangan yang dimiliki pemerintah Kabupaten/Kota dalam memberikan izin suatu permohonan suatu investasi tidak perlu dipermasalahkan karena ketentuan hukumnya telah mengatur demikian sesuai kewenangan yang diatur dalam Undang-Undang Otonomi Daerah. Hal terpenting yang perlu dilakukan dalam pengaturan hukum investasi pariwisata di Provinsi Bali adalah norma hukum tata ruang Bali yang diatur dalam RTRW Provinsi Bali harus bisa dijabarkan lebih lanjut dalam rencana detail tata ruang Kabupaten/Kota (RDTRK) di setiap Kabupaten/Kota se Bali. Apabila pemerintah Kabupaten/Kota telah memiliki rencana detail tata ruang dan di dalamnya diatur penempatan lokasi penanaman modal di bidang pariwisata maka ada beberapa tujuan strategis yang dapat diperoleh :

1. Di pihak investor, dengan adanya rencana detail tata ruang akan diperoleh transparansi informasi yang rinci dan akurat tentang kejelasan lokasi yang boleh dimohonkan untuk investasi pariwisata, calon investor akan memperoleh akses informasi yang terbuka tentang kepastian hukum dan kepastian ekonominya. Kepastian hukum adalah faktor yang sangat penting bagi calon investor untuk melakukan rencana investasinya. Selama ini banyak calon investor ragu untuk berinvestasi karena adanya ketidakpastian hukum menyangkut perizinnya. Sebagai contoh aktual yang terjadi saat ini di Kabupaten Badung, berdiri bangunan villa villa mewah di daerah Pura Ulu Watu yang diprotes warga setempat karena dianggap melanggar radius kesucian Pura. Pemerintah Provinsi Bali menyalahkan pemerintah kabupaten Badung karena sesuai dengan ketentuan tentang radius kesucian Pura dalam RTRW Bali adalah 5.000 m untuk Pura Sad Kahyangan sejenis Pura Ulu Watu, sedangkan pemerintah kabupaten Badung mengizinkan pembangunan villa pada radius kurang dari $5.000 \mathrm{~m}$. Saat ini terjadi polemik publik berkepanjangan yang melibatkan para tokoh adat dan agama, budayawan, intelektual, birokrat, politisi dan generasi muda Bali. Perizinan villa-villa tersebut dikhawatirkan dicabut. Apabila kasus ini terpublikasi secara internasional akan berdampak buruk terhadap iklim investasi di Bali. Sesungguhnya investasi sangat dibutuhkan kehadirannya tetapi harus ada kepastian hukum yang sudah diformat baik pada level perencanaan, operasional maupun penegakan hukumnya. Sehingga berjalannya investasi seiring berjalan dengan pelestarian alam dan budaya Bali sebagai asset pariwisata. Demikian pula kepastian ekonomi juga merupakan faktor

39 Ibid. 
penting bagi calon investor untuk menanamkan investasinya. Sudah barang tentu calon investor akan melakukan analisa ekonomi yang matang dan akurat terhadap keputusan usaha yang akan dilakukannya, mengingat investasi di bidang pariwisata membutuhkan dana yang relatif besar. Dengan adanya keterbukaan dan transparansi informasi yang dituangkan dalam rencana detail tata ruang tersebut maka calon investor sudah mengalkulasi resiko ekonomi yang akan terjadi. Dengan adanya transparansi dan informasi yang terbuka dari pihak Pemerintah Daerah Kabupaten/Kota termasuk juga di dalamnya ada kewajiban hukum berupa dukungan dari masyarakat adat yang diwakili oleh pemerintahan Desa Pakraman yang menyangkut keamanan usahanya, tenaga kerja dan beban sosial perusahaan yang wajib dialokasikan kepada desa Pakraman, barulah calon investor akan memutuskan rencana investasinya. Bila kedua faktor ini telah memperoleh gambaran jelas lengkap dan akurat barulah calon investor merealisir investasinya.

2. Di pihak pemerintah sebagai regulator yang mengeluarkan izin investasi akan bisa merencanakan pembangunan daerahnya lebih profesional, baik secara yuridis memenuhi azas kepastian hukum investasi dan secara ekonomis mampu menyejahterakan perekonomian rakyat kecil dan menengah yang menjadi bagian terbesar penduduk daerahnya dengan memanfaatkan potensi dan prospek yang bisa diharapkan dari adanya usaha pariwisata tersebut. Ini berkaitan erat dengan program pembangunan daerah Kabupaten/kota, dengan kewenangan yang lebih luas yang diberikan UU.PD akan dituntut pula tanggung jawab yang lebih besar untuk pembangunan daerahnya. Pembangunan daerah membutuhkan pembiayaan besar dan sumber dananya dapat diharapkan dari Pendapatan Asli Daerah (PAD) yang bersumber dari pajak perusahaan dan sumber lainnya yang ada di daerahnya.

3. Di pihak masyarakat adat Bali yang representasinya Desa Pakraman (sebagaimana diatur dalam Perda Provinsi Bali No. 3 Tahun 2003), akan merasa nyaman hidup di lingkungan palemahannya (teritorial Desa Adat) karena investasi pariwisata sudah mengikuti rencana detail tata ruang Kabupaten/Kota yang telah mengakomodir falsafah Tri Hita Karana sebagai sumber kehidupan masyarakat Bali yang terbentuk dalam adat istiadatnya. Selama ini banyak izin investasi ditolak dengan berbagai protes dan demo dari masyarakat adat, substansi masalahnya adalah proses perizinannya tanpa melibatkan masyarakat. Masyarakat bukan menolak investasi, justru masyarakat sangat paham arti pentingnya investasi dalam membangun daerahnya. Namun demikian masyarakat harus mendapatkan jaminan bahwa lingkungan alamnya sebagai penyangga aktivitas adat istiadat dan budaya berlandaskan nilai agama Hindu dan falsafah Tri Hita Karana tetap terjaga kelestariannya. Bila kondisi demikian yang diharapkan oleh masyarakat adat berarti tuntutan tersebut sinkron dengan keinginan para investor pariwisata sebab yang menjadi asset bisnis pariwisata adalah kelestarian alam dan budaya Bali.

Bertitik tolak dari tiga tujuan strategis tersebut ada sinergitas dalam pemanfaatan alam dan budaya Bali sebagai asset pariwisata. Investor sebagai pemilik modal akan memperoleh keuntungan sesuai tujuan bisnisnya, Pemerintah Daerah Kabupaten/Kota mendapatkan sumber pendapatan (antara lain melalui PAD) dari pajak dan iuran sesuai kewenangannya dan masyarakat Bali dapat hidup nyaman dan damai karena alam dan budaya Bali terjamin kelestariannya.

Inilah sesungguhnya substansi tujuan dari falsafah Tri Hita Karana yang secara turun temurun telah mentradisi dalam keseharian kehidupan masyarakat adat di Bali. Dalam 
kontek kekinian falsafah ini juga sangat relevan untuk di reaktualisasi dalam ranah instrumental dengan mengakomodasikannya dalam bentuk pengaturan hukum investasi pariwisata di Bali.

\section{Kesimpulan}

Secara umum hukum investasi dalam kerangka industri pariwisata di Provinsi Bali, ditandai oleh inkonsistensi penerapan hukum, yang cenderung melenyapkan objek pariwisata itu sendiri. Regulasi hukum investasi yang menjadikan 'pariwisata budaya' sebagai industri primadona di Provinsi Bali membukukan sejumlah fakta, yakni capaian yang terbilang sangat fenomenal, kesenjangan atau ketidak-adilan secara sosial, praktek investasi pariwisata yang menafikan kosmologi Tri Hita Karana, regulasi hukum yang sekadar sinkron dan harmonis dengan peraturan yang lebih tinggi, atau sederajat, dan inkonsistensi penerapan hukum.

\section{Daftar Pustaka}

Buku

Bratakusumasa. Supriady, D. \& Solihin, D. (2002). Otonomi Penyelenggaraan Pemerintahan Daerah. Jakarta: PT. Gramedi Pustaka Utama.

Darmaputera, E. (1988). Pancasila Identitas dan Modernitas: Tinjauan Etis dan Budaya.. Jakarta: Gunung Mulia.

Deyo, F. C. (1987). The political economy of the new Asian industrialism. USA: Cornell University Press.

Ihromi, T.O. (1993). Antropologi Hukum, Sebuah Bunga Rampai. Jakarta: Yayasan Obor Indonesia.

Lubis, T. M., \& Buxbaum, R. M. (1986). Peranan Hukum dalam Perekonomian di Negara Berkembang. Jakarta: Yayasan Obor Indonesia.

Nasution, M. A. (2000). Demokratisasi E Problem Otonomi Daerah. Bandung: CV. Mandar Maju.

Palguna, D. G. (2008). Saya Sungguh Mencemaskan Bali. Jakarta: Mahkamah Konstitusi.

Pangdjaja. I B. (1991). Bali Apa Kata Mereka. Denpasar: Mabhakti.

Putra, I. B. W. (1998). Bali dalam perspektif global. Denpasar: Upada Sastra.

Sumantoro. (1986). Hukum ekonomi. Jakarta: Penerbit Universitas Indonesia.

Sutjipta, N. (2005). Pariwisata Revolusi di Pulau Dewata. Denpasar: Universitas Udayana Press.

Trubek, D. M. (1991). Max Weber on Law and the Rise of Capitalism. London: Routledge. 


\section{Jurnal}

Choudhury, N. (2017). Revisiting Critical Legal Pluralism: Normative Contestations in the Afghan Courtroom. Asian Journal of Law and Society, 4(1), 229-255. https://doi.org/10.1017/als.2017.2

Curdia, V., \& Woodford, M. (2010). Credit spreads and monetary policy. Journal of Money, Credit and Banking.42(s1). 3-35. https://doi.org/10.1111/j.1538$\underline{4616.2010 .00328 . x}$

Edelman, L. B., Krieger, L. H., Eliason, S. R., Albiston, C. R., \& Mellema, V. (2011). When organizations rule: Judicial deference to institutionalized employment structures. American Journal of Sociology. 117(3). 888-954. https://doi.org/10.1086/661984

Endraswati, H., \& Wahyuni, S. (2015). Operationalization of Shariah Marketing Mix in Baitul Maal Wat Tamwil (BMT) at the Province of Banten, Indonesia. Review of Integrative Business and Economics Research. 4(1). 41-48

Suatmaja, G. D. (2016). Peranan Majelis Desa Pakraman Bali Dalam Pelaksanaan Investasi Kepariwisataan Di Wilayah Desa Pakraman. Jurnal Magister Hukum Udayana (Udayana Master Law Journal). $5(2) .353 \quad$ - 367. https://doi.org/10.24843/JMHU.2016.v05.i02.p10

Kristian, D., Suyatna, I. N., \& Dahana, C. D. (2014). Kewenangan Pemerintah Daerah Dalam Pengadaan Tanah Bagi Pelaksanaan Pembangunan Untuk Kepentingan Umum. Kertha Negara. 2(01).

Pramadita, I. (2017). Perjanjian Kerjasama Pengelolaan Pariwisata Tanah Lot Antara Pemerintah Daerah Kabupaten Tabanan Dengan Desa Pakraman Beraban Dalam Perspektif Keadilan Dan Kepastian Hukum. Jurnal Magister Hukum Udayana (Udayana Master Law Journal). $6(1) .52$ - 66. https://doi.org/10.24843/JMHU.2017.v06.i01.p05

Prijandhini Devi Salain, M. (2015). Pengaturan City Hotel Berkarakter Chain Hotel Sebagai Salah Satu Bentuk Usaha Jasa Pariwisata Di Indonesia (Studi Kasus Di Bali). Jurnal Magister Hukum Udayana (Udayana Master Law Journal). 4(4), 783795. https://doi.org/10.24843/JMHU.2015.v04.i04.p17

\section{Disertasi}

Gelgel, I. P. (2008) Kearifan Lokal Dalam Pembangunan Hukum Pariwisata di Tengah Arus Globalisasi Perdagangan Jasa. Disertasi. Semarang. Program doktor Ilmu Hukum Universitas Diponegoro.

Steeman, T. M. (1973). Religious Pluralism and National Integration. Disertation. USA. Harvard University.

Triguna, Y. (1997). Mobilitas Kelas, Konflik, dan Panafsiran Kembali Simbolisme Masyarakat Bali. Disertasi. Bandung. Universitas Padjadjaran. 


\section{Peraturan Peundang-undangan}

Undang-Undang Republik Indonesia Nomor 32 Tahun 2004 Tentang Pemerintah Daerah

Undang-undang Republik Indonesia Nomor 26 Tahun 2007 Tentang Penataan Ruang Undang-Undang Republik Indonesia Nomor 25 Tahun 2007 Tentang Penanaman Modal

Undang-Undang Republik Indonesia Nomor 10 Tahun 2009 Tentang Kepariwistaan

Peraturan Daerah Provinsi Bali Nomor 3 Tahun 2003 Tentang Perubahan Atas Peraturan Daerah Propinsi Bali Nomor 3 Tahun 2001 Tentang Desa Pakraman

\section{Majalah/Koran}

Palguna, D. G. (2008). Implementasi THK dalam Aspek Hukum : Realitas, Harapan, dan Rekomendasi, dalam : Bali is Bali Forever. Denpasar. Bali Travel News.

Pitana, G. (2008). Bali is Bali Forever: Ajeg dalam Bingkai Tri Hita Karana. Denpasar. Bali Post.

Suparta, W. (1999). Bali dan Masa depan. Denpasar. Bali Post.

Wignjosoebroto, S. (2002). Hukum, Paradigma, Metode dan Dinamika Masalahnya. Jakarta. Lembaga Studi Hukum dan Advokasi Masyarakat (ELSAM). 